DOI: https://doi.org/10.32836/2521-666X/2020-67-6

УДК 338.48 (477)

Передерко В.П.

кандидат історичних наук, доцент, доцент кафедри туризму,

Івано-Франківський національний технічний університет нафти і газу

Perederko Vitaliy

Ivano-Frankivsk National Technical University of Oil and Gas

\title{
АНАЛІЗ ПОТОКІВ ВНУТРІШНЬОГО ТУРИЗМУ В ІВАНО-ФРАНКІВСЬКІЙ ОБЛАСТІ У 2018 Р. ЗА ДАНИМИ МОБІЛЬНОГО ЗВ'ЯЗКУ. ЧАСТИНА $3^{1}$
}

\section{DOMESTIC TOURISM FLOWS OF IVANO-FRANKIVSK REGION ANALYSIS BASED ON MOBILE COMMUNICATION DATA IN 2018. PART 3}

У статті проаналізовано короткотермінові міжрегіональні переміщення населення України у 2018 р. в контексті вивчення внутрішніх туристичних потоків у розрізі адміністративно-територіальних одиниць (локальних дестинацій) ІваноФранківської області на основі моніторингу міжрегіональної мобільності абонентів оператора стільникового зв'язку. Увагу зосереджено на відвідуваності м. Яремче. Офіиійна статистика не може відображати достовірну картину туристичних потоків через недосконалість методології розрахунку. Наша мета полягає в оціниі таких потоків на основі інноваційного підходу через моніторинг та аналіз даних переміщення абонентів. Моніторинг мобільності не є панацеєю, адже обмежений переважсно тим, що не містить інформаиії про мету короткочасного гостьового перебування абонентів, тому ми не можемо всіх їх без винятку зараховувати до екскурсантів чи туристів. Однак застосування такого інновачійного підходу для кількісного й якісного вимірів відвідуваності регіону є перспективним напрямом досліджень. Яремче.

Ключові слова: внутрішній туризм, статистика, мобільність, локальна дестинація, Івано-Франківська область,

В статье проанализированы краткосрочные межрегиональные перемещения населения Украины в 2018 в контексте изучения внутренних туристических потоков в разрезе административно-территориальных единии (локальных дестинаций) Ивано-Франковской области на основе мониторинга межрегиональной мобильности абонентов оператора сотовой связи. Внимание сосредоточено на посещаемости г. Яремче. Официальная статистика не может отражать достоверную картину туристических потоков из-за несовершенства методологии расчета. Наша цель заключается в оиенке таких потоков на основе инновационного подхода через мониторинг и анализ данных перемещения абонентов. Мониторинг мобильности не является паначеей, ведь он ограничен в основном тем, что не содержит информации о иели кратковременного гостевого пребывания абонентов, поэтому мы не можем всех их без исключения отнести к экскурсантам или туристам. Однако применение такого инноваџионного подхода для количественного и качественного измерения посещаемости региона является перспективным направлением исследований.

Ключевые слова: внутренний туризм, статистика, мобильность, локальная дестинация, Ивано-Франковская область, Яремче.

Official statistics cannot reflect the true picture of domestic tourism flows entering the Precarpathian region because of the imperfection of the methodology for calculating. The purpose of the article is to provide an approximate domestic tourism flows estimation based on data analysis that illustrate the movement of subscribers of the mobile communication in terms of the administrative districts of Ivano-Frankivsk region. Mobility monitoring is limited; first, by the fact that it does not contain information about the purpose of subscribers' short-term stay in a certain territory; therefore, we cannot all of them count as excursionists or tourists without exception. However, the application of the innovative approach of domestic tourism flows analyzes and quantitative measuring of region's attendance based on monitoring of interregional mobility of communication operator subscribers is a promising direction for further researches. The article is devoted to the short-term interregional movements (migrations) of the population of Ukraine analyzes in the context of studying the domestic tourism flows of Prykarpattya in terms of administrative districts (local destinations) of Ivano-Frankivsk region based on monitoring of interregional mobility of the communication operator subscribers in 2018. The Yaremche city's guest flows are in the article's focus. The guest regions (cities) of Ukraine with the largest numbers visitors for Yaremche city were determined. Investigated seasonality of movements (migrations) and visitors'stay duration allowed to identify mobility patterns, traffic transit signs, etc. In line with collected data based on movement monitoring (duration of stay from 1 to 7 days), Yaremche city thought to be one of the most visited districts of Ivano-Frankivsk region. Over 0.25 million guest subscribers have been recorded in Yaremche city, including almost 126 thousand subscribers - with overnight stays. Only about

\footnotetext{
1 Закінчення. Початок див.: Передерко В.П. Аналіз потоків внутрішнього туризму в Івано-Франківській області у 2018 р. за даними мобільного зв'язку. Частина 1. Актуальні проблеми розвитку економіки регіону. 2019. Вип. 15. Т. 2. С. 52-64; Передерко В.П. Аналіз потоків внутрішнього туризму Івано-Франківській області у 2018 р. за даними мобільного зв'язку. Частина 2. Науковий вісник Ужгородського національного університету. Серія «Міжнародні економічні відносини та світове господарство». 2019. Вип. 29. С. 108-113.
} 
$15 \%$ of the guests stayed in the city for two or more nights. It is an evidence of "tourist transit". The mobile network data use in means of statistical information in the field of tourism is of a great importance for the region's economy, since tourism is one of the regional development priorities.

Key words: domestic tourism, statistics, mobility, local destination, Ivano-Frankivsk region, Yaremche city.

Постановка проблеми. Важливу роль для оцінки внеску туризму в економіку держави відіграє облік туристів. Сьогодні необхідні обгрунтовані статистичні заміри з метою визначення стратегічних напрямів розвитку туристичної і супутньої інфраструктури, організації маркетингових заходів для просування туристичного продукту на внутрішньому та зовнішньому ринках.

Аналіз останніх досліджень і публікацій. Різні аспекти міжнародного i внутрішнього туризму $є$ предметом досліджень таких науковців, як I. Ангелко, С. Грабовенська, Т. Грачевська, М. Колосінська, А. Парфіненко. Питання просторової мобільності населення вивчають О. Грішнова, М. Долішній, Е. Лібанова, О. Малиновська, С. Сардак, О. Шаблій та ін. Аналізом специфіки просторової мобільності через призму міграцій і туризму займається М. Біль.

Незважаючи на велику кількість наукових публікацій із питань удосконалення в Україні методики i методології статистичного обліку у сфері туризму, дослідження різних аспектів просторової мобільності населення, міграцій як одного з напрямів реалізації високого рівня мобільності, використання в туризмі даних переміщень абонентів мереж мобільного зв'язку $\epsilon$ сьогодні маловивченою темою. На нашу думку, рівень розгляду та вирішення у дослідженнях теоретичних і емпіричних завдань, пов'язаних із методологією комплексного аналізу інформації таких переміщень (міграцій), є недостатнім. Територіальна (просторова) туристична мобільність заслуговує на більшу увагу та може входити до пріоритетних об’єктів наукових досліджень учених у галузях економіки і статистики.

Мета статті полягає у приблизній оцінці внутрішніх туристичних потоків у 2018 р. в розрізі адміністра- тивно-територіальних одиниць (локальних дестинацій) Івано-Франківської області через застосування інноваційного підходу до статистичного обліку на основі аналізу даних переміщень (міграцій) абонентів мережі мобільного зв'язку.

Основні завдання дослідження: охарактеризувати короткотермінові міжрегіональні переміщення (міграції) абонентів у контексті вивчення внутрішніх туристичних потоків; визначити географію відвідувачів; проаналізувати показники сезонності переміщень (міграцій) і тривалості перебування абонентів - потенційних внутрішніх туристів - у м. Яремче.

Виклад основного матеріалу. У дослідженні проаналізовано: кількість унікальних абонентів, які приїжджали протягом 2018 р. до м. Яремче, із зазначенням регіону прибуття (область чи обласний центр України переважного місцезнаходження абонентів «Київстар»); тривалість перебування абонентів у межах обласного центру (1, 2-3, 4-7 днів). Інформація отримана у помісячному розподілі для аналізу сезонності.

За даними моніторингу мобільності, отриманими від компанії «Київстар», відкаліброваними відповідно до нашої методики [1], у 2018 р. в Івано-Франківській області в усіх районах та містах обласного значення було зафіксовано 2,81 млн. абонентів із 23 областей України, 3 них - 1,38 млн. короткотермінових відвідувачів (у т. ч. туристів) та 1,42 млн. одноденних відвідувачів (у т.ч. екскурсантів) [2] (рис. 1-2).

Раніше ми з'ясували, що найвідвідуванішими локальними дестинаціями Івано-Франківської області з тривалістю перебування 2-7 днів упродовж 2018 р. стали: Надвірнянський район (із територією Яремчанської міської ради без м. Яремче), міста Івано-Франківськ і Яремче, Косівський, Верховинський райони [3, с. 57].

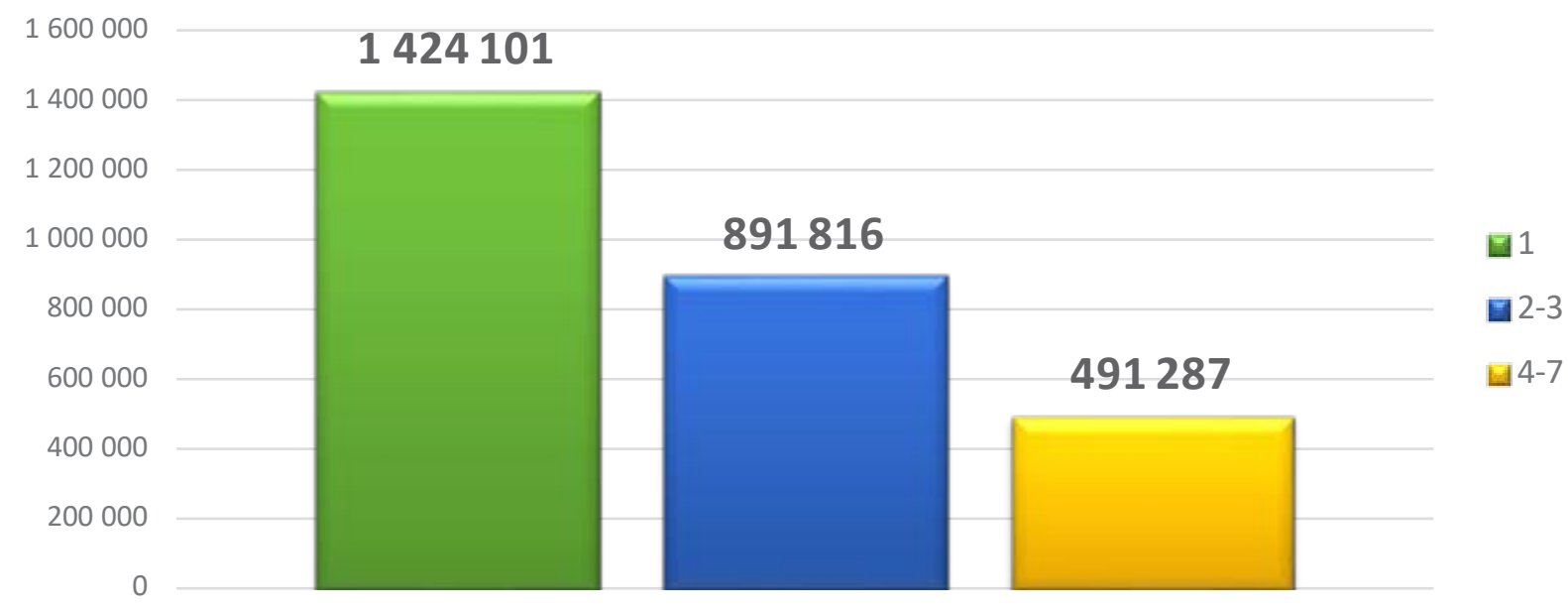

Рис. 1. Тривалість перебування абонентів в Івано-Франківській області, 2018 р. (осіб)

Джерело: авторська розробка на основі [2] 


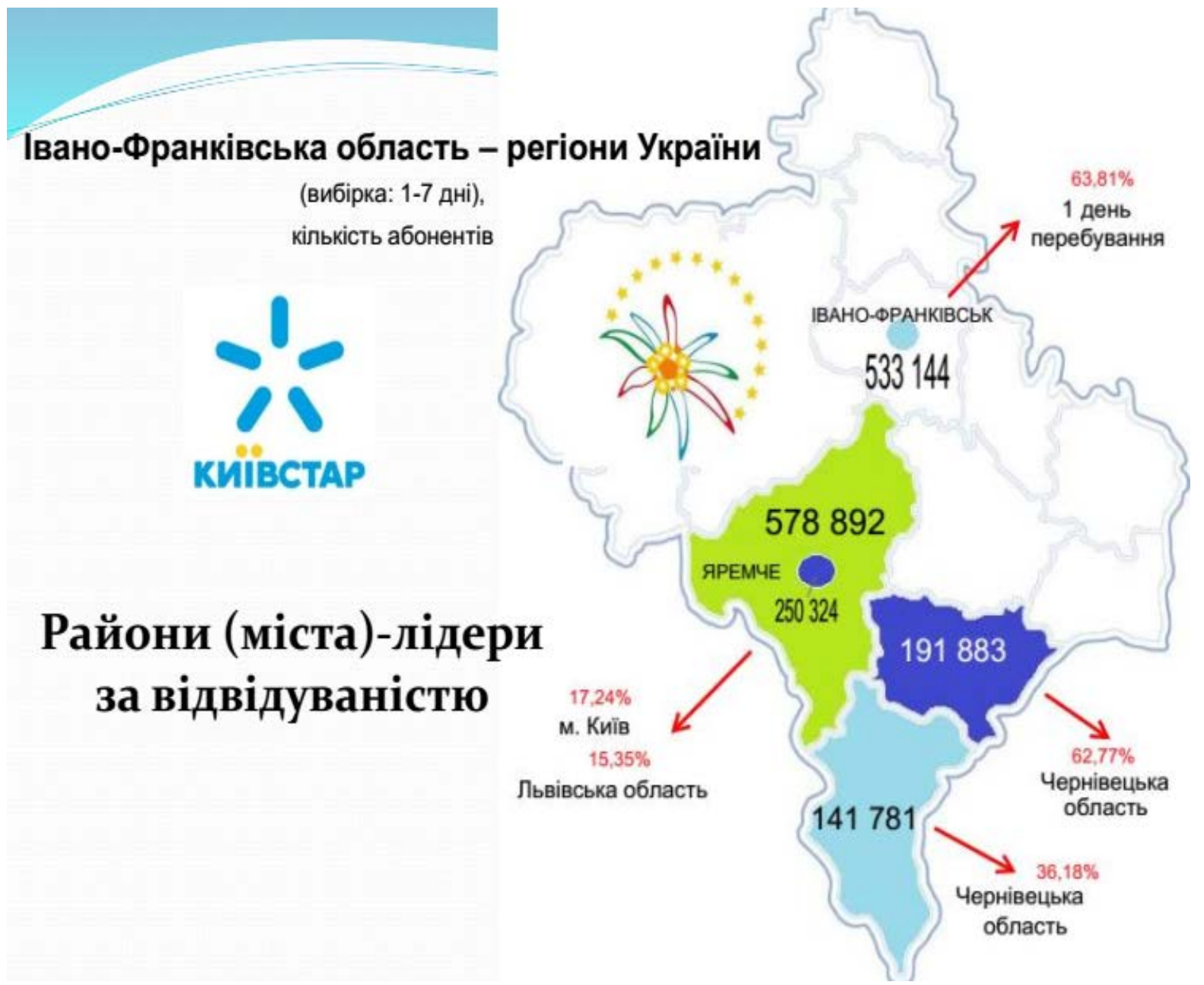

Рис. 2. Райони (міста) - лідери Івано-Франківської області з найбільшою відвідуваністю, 2018 р. (осіб) Джерело: авторська розробка на основі [2]

Перейдемо до характеристики міжрегіональних потоків в окремих адміністративно-територіальних одиницях Івано-Франківської області. У цій частині дослідження зосередимося на м. Яремче.

Яремче. Місто зайняло третє місце в області за відвідуваністю абонентами інших регіонів України y 2018 p.

Моніторинг зафіксував, що до цієї адміністративної локації у 2018 р. приїздило 250324 особи, 3 них майже 130 тис абонентів - із ночівлями. Але лише $15 \%$ гостей ночували у місті дві і більше ночей [2] (рис. 3).

У м. Яремче фіксується чітка сезонність гостьового потоку. Найчастіше до цієї локальної дестинації приїжджають улітку; заслуговує на увагу також січнева відвідуваність - виразний туристичний тренд мобільності [2]. До п'ятірки регіонів (міст), мешканці яких найчастіше приїжджали до цієї локальної дестинації, увійшли м. Київ $(15,38 \%$ сумарного гостьового потоку м. Яремче), Львівська (12,97\%), Тернопільська (9,63\%), Хмельницька (8,84\%), Вінницька (7,26\%) області [2] (рис. 4).

Далі у порядку зменшення кількості відвідувачів йдуть мешканці Одеської, Дніпропетровської, Київської, Рівненської та Житомирської областей [2]. Най- більш висока частка одноденного відвідування/перебування абонентів у м. Яремче зафіксована, насамперед, для сусідніх з Івано-Франківщиною регіонів. Це Закарпатська (77,56\% сумарного потоку гостьового регіону), Чернівецька $(66,35 \%)$ і Тернопільська $(59,38 \%)$ області [2]. Також надмірна транзитність спостережувана для абонентів Волині - 56,48\% [2].

Порівнюючи гостьову мобільність абонентів українських областей до м. Яремче у 2017 та 2018 рр. у розрізі регіонів, спостерігаємо, що впродовж 2018 р. показники притоку абонентів майже не змінилися. Невелике зростання зафіксоване для відвідувачів з Одеської, Миколаївської та Волинської областей $-+18,54 \%$, $+18,43 \%,+17,98 \%$ відповідно [2; 4].

Аналіз мобільності гостьових потоків до м. Яремче 3 обласних центрів засвідчив, що найчастіше у 2018 p. до міста приїжджали мешканці Києва, Львова, Тернополя, Хмельницького та Одеси [2]. Далі у порядку зменшення кількості відвідувачів йдуть гості з Вінниці, Рівного, Дніпра, Харкова, Чернівців [2].

Найбільша частка абонентів обласного центру у сукупномупотоцігостьового регіонузафіксованадля мешканців Харкова (79,63\%), Києва $(74,08 \%)$, Запоріжжя 


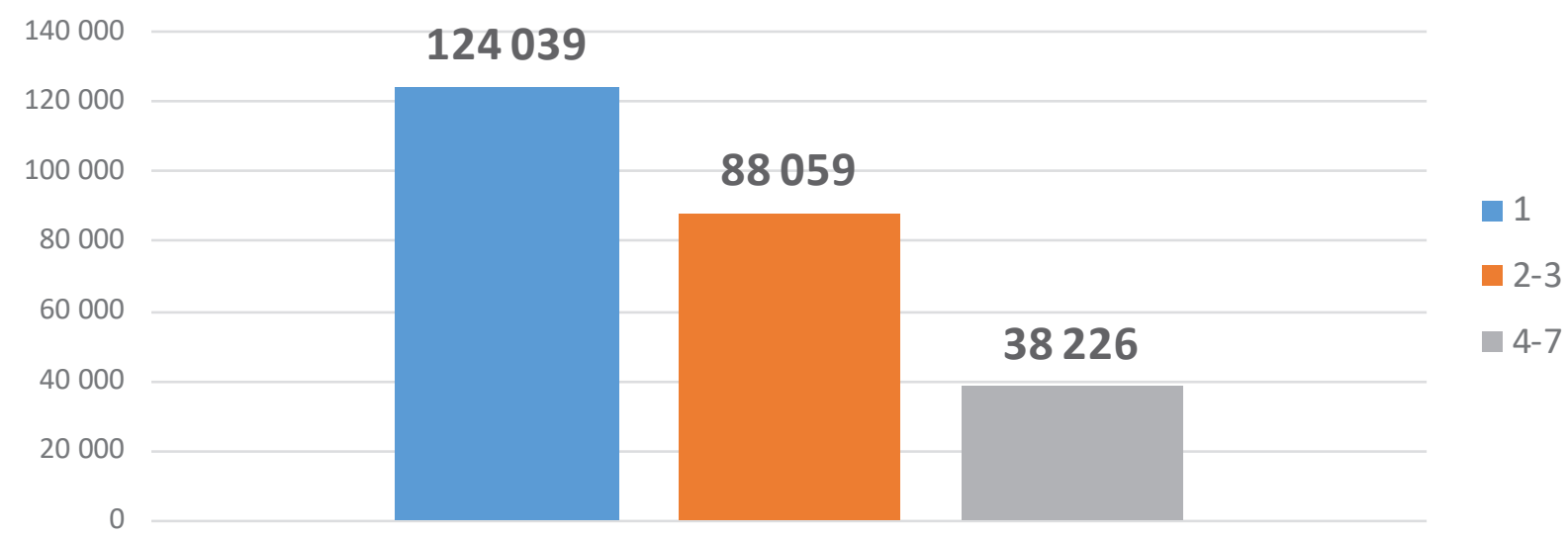

Рис. 3. Розподіл тривалості короткострокового перебування абонентів у м. Яремче, 2018 р. (осіб) Джерело: авторська розробка на основі [2]

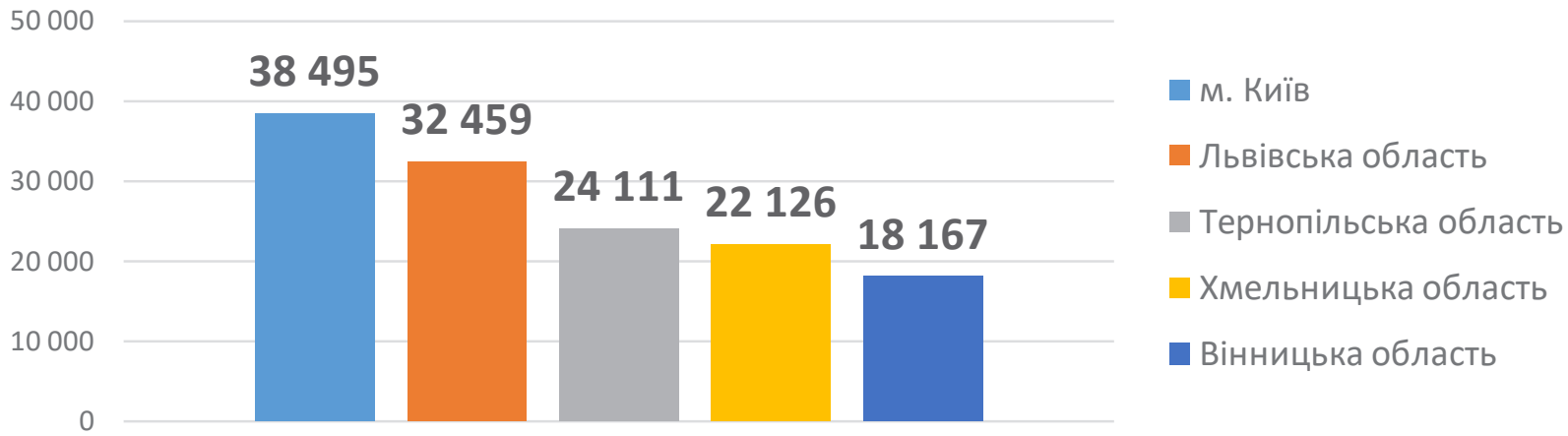

Рис. 4. Регіони (міста) - лідери короткострокового перебування у м. Яремче, 2018 р. (осіб)

Джерело: авторська розробка на основі [2]

(64,29\%), Одеси (63,54\%), Львова (60,49\%) [2]. Найбільший приріст відвідувачів м. Яремче серед інших обласних центрів зафіксовано для абонентів Луцька $(+16,56)$ та Одеси $(+15,80 \%)$, найбільше падіння - Черкас $(-7,51 \%)$ і Сум $(-7,08 \%)$ [2].

Моніторинг мобільності абонентів у розрізі регіонів (міст) із найбільшою кількістю відвідувачів через призму сезонності перебування у м. Яремче демонструє зимовий та літній тренди для територіально віддалених регіонів і літній тренд для сусідніх з Івано-
Франківською областю регіонів. Проілюструємо це через візуалізацію даних мобільності мешканців Києва і Львівської області [2] (рис. 5, 6).

В абсолютних цифрах найбільше відвідувачів із кількома ночівлями в розрізі місяців 2018 р.м. Яремче прийняло у липні - 7,7 тис гостей [2]. Серед лідерів - мешканці Київської (з м. Київ), Львівської, Дніпропетровської, Одеської, Хмельницької областей [2] (рис. 7). Топова гостьова п’ятірка регіонів займає частку 60\% [2]. При цьому частка Київщини як лідера

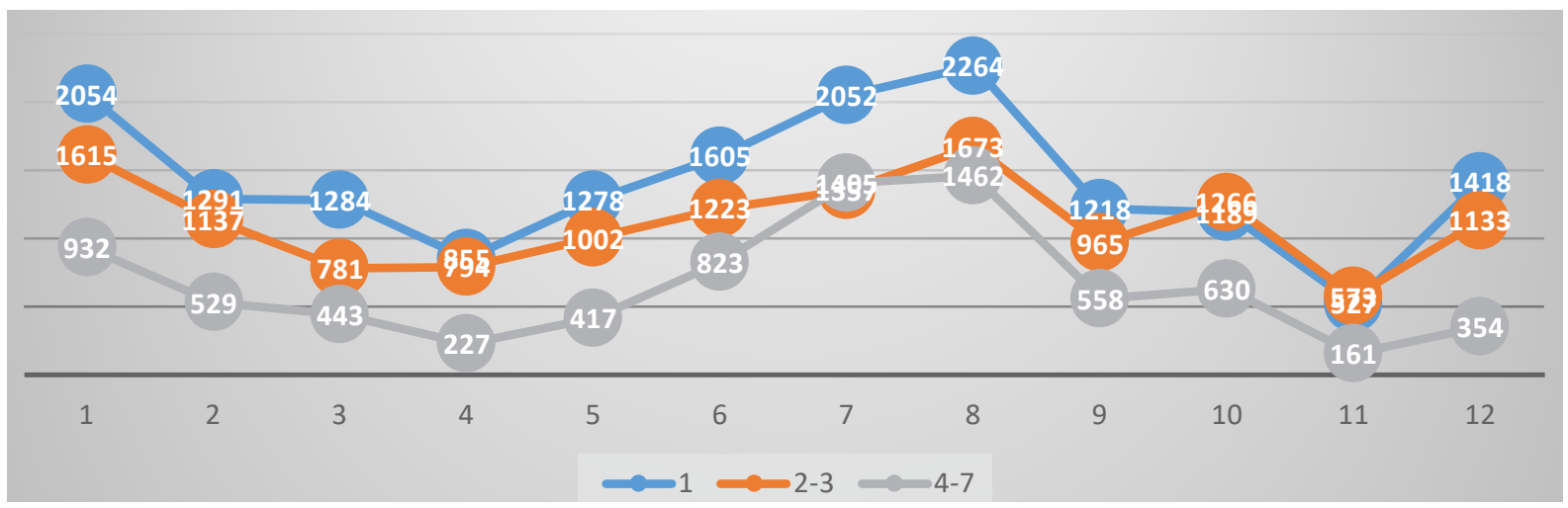

Рис. 5. Гостьова мобільність абонентів м. Кисва до м. Яремче, 2018 р. (осіб)

Джерело: авторська розробка на основі [2] 


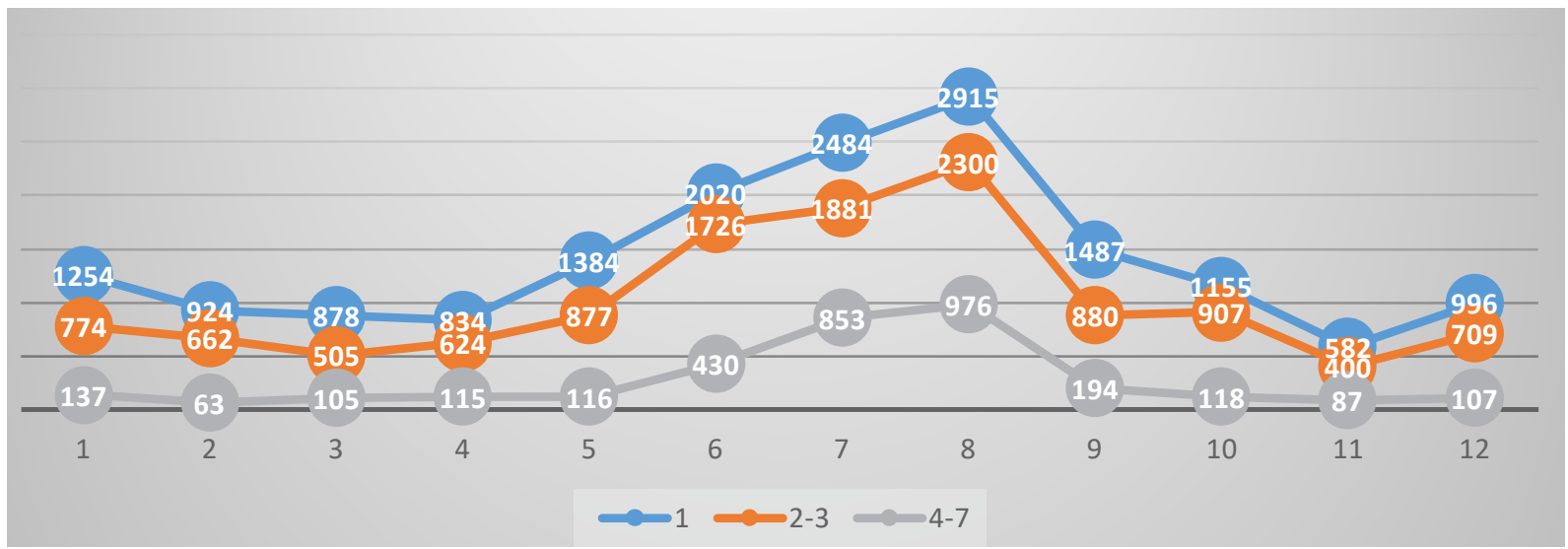

Рис. 6. Гостьова мобільність абонентів Львівської області до м. Яремче, 2018 р. (осіб)

Джерело: авторська розробка на основі [2]

гостьового потоку становить аж $28 \%$, і здебільшого це мешканці столиці [2].

Серед зимових місяців домінуючим за відвідуваністю є січень - 4,6 тис відвідувачів [2]. Серед лідерів - мешканці Київської (з м. Київ), Дніпропетровської, Одеської, Запорізької, Харківської областей [2] (рис. 8).

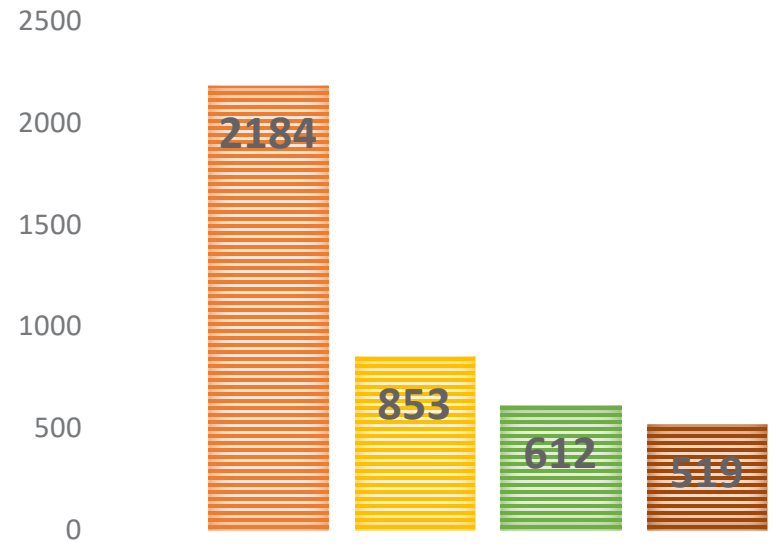

Топова п’ятірка гостьових регіонів займає частку $68 \%, 28 \%$ гостей січня у м. Яремче - мешканці Київщини, і знову ж таки переважно це - кияни [2].

Якщо розширити вибірку до тривалості перебування 2-7 днів, то місяці-лідери такі: у січні м. Яремче відвідало понад 14 тис осіб, у серпні - понад 19 тис осіб [2]. Ці цифри підтверджують наше спостереження на даних

Рис. 7. Регіони - лідери короткострокового перебування в м. Яремче (4-7 днів), липень 2018 р. (осіб) Джерело: авторська розробка на основі [2]

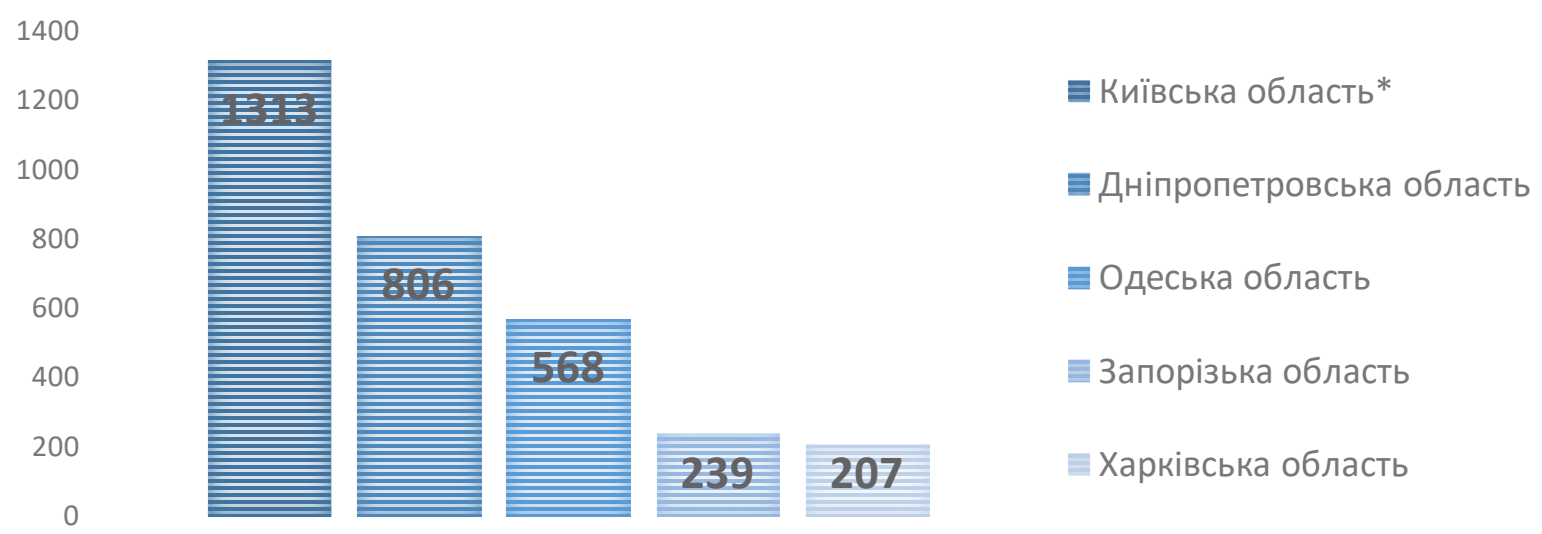

Рис. 8. Регіони - лідери короткострокового перебування в м. Яремче (4-7 днів), січень 2018 р. (осіб) Джерело: авторська розробка на основі [2] 
2017 р. про те, що місто є своєрідними туристичними воротами Карпат, яке вибирають, насамперед, для нетривалого відпочинку, зокрема екскурсій [1, с. 62].

Висновки. Місто Яремче - один із лідерів за показником відвідуваності серед адміністративно-територіальних одиниць Івано-Франківської області.

Моніторинг зафіксував, що до цієї адміністративної локації у 2018 р. приїздило 250324 особи, з них майже 130 тис абонентів - із ночівлями. У м. Яремче фіксується чітка сезонність гостьового потоку. Найчастіше до міста приїжджають улітку та на новорічно-різдвяний період. При цьому спостерігається літній тренд гостьового потоку для сусідніх з Івано-Франківською областю регіонів і зимовий та літній тренди для територіально віддалених регіонів.

До п’ятірки регіонів (міст), мешканці яких найчастіше приїжджали до цієї локальної дестинації, увійшли м. Київ (15,38\% сумарного гостьового потоку м. Яремче), Львівська (12,97\%), Тернопільська (9,63\%), Хмельницька (8,84\%), Вінницька (7,26\%) області.
Лідерські позиції міста підриває вагомий недолік. Моніторинг зафіксував, що лише 15\% гостей у 2018 р. ночували у м. Яремче дві і більше ночей. Це явище можна умовно назвати «туристичною транзитністю». Туристичний потенціал та інфраструктура міста мають історично зумовлену специфіку, у новітній час розвиток курорту відбувався по висхідній, але хаотично. Сьогодні наслідками цієї хаотичності стала надмірна забудованість території готельно-відпочинковими комплексами (у т.ч. у межах заповідних природних комплексів та об'єктів), що стоїть перепоною для розвитку індустрії рекреаційного і пізнавального дозвілля. У м. Яремче важко знайти вільні площі для створення атракцій із потенціалом туристичних магнітів. Останні мають стати причиною затримування відвідувачів, а отже, їх тривалішого перебування. Долати транзитність точковими заходами (наприклад, проводити фестивалі) для міста - не рішення. Місто Яремче має потенціал туристичного зростання і його варто використати.

\section{Список літератури:}

1. Передерко В.П. Аналіз потоків внутрішнього туризму в Івано-Франківській області у 2017 р. за даними мобільного зв’язку. Частина 2. Регіональна економіка та управління. 2019. № 2(24). С. 56-66.

2. Інформація про мобільність населення. 2018 рік. Калібровані дані (Україна - Івано-Франківська область).

3. Передерко В.П. Аналіз потоків внутрішнього туризму в Івано-Франківській області у 2018 р. за даними мобільного зв'язку. Частина 1. Актуальні проблеми розвитку економіки регіону. 2019. Вип. 15. Т. 2. С. $52-64$.

4. Інформація про мобільність населення. 2017 рік. Калібровані дані (Україна - Івано-Франківська область).

1. Perederko V.P. (2019) Analiz potokiv vnutrishn`ogo tury`zmu v Ivano-Frankivs `kij oblasti u 2017 r. za dany`my` mobil’nogo zv'yazku. Chasty'na 2 [Domestic tourism flows of Ivano-Frankivsk region analysis based on mobile communication data in 2017. Part 2]. Regional Economics and Management, no. 2(24), pp. 56-66.

2. Informaciya pro mobil'nist naselennya. 2018 rik. Kalibrovani dani (Ukrayina - Ivano-Frankivs`ka oblast') [Population mobility. 2018. Calibrated data (Ukraine - Ivano-Frankivsk region)].

3. Perederko V.P. (2019) Analiz potokiv vnutrishn`ogo tury`zmu v Ivano-Frankivs`kij oblasti u 2018 r. za dany`my` mobil 'nogo zv’yazku. Chasty`na 1 [Domestic tourism flows of Ivano-Frankivsk region analysis based on mobile communication data in 2018. Part 1]. The actual problems of regional economy development, vol. 2, no. 15 (2019), pp. 52-64.

4. Informaciya pro mobil'nist` naselennya. 2017 rik. Kalibrovani dani (Ukrayina - Ivano-Frankivs 'ka oblast') [Population mobility. 2017. Calibrated data (Ukraine - Ivano-Frankivsk region)]. 